\title{
BORIS PASTERNAK WOBEC PRZEMIAN CYWILIZACYJNYCH
}

\author{
BORIS PASTERNAK AND CIVILIZATIONAL TRANSFORMATIONS
}

\author{
ZYGMUNT ZBYROWSKI
}

\begin{abstract}
AвSTRACT. Boris Pasternak made use of available means of transport and communication on a daily basis. This fact, however, was not reflected in his autobiographical writings, correspondence and his oeuvre. The sole exception was the railway, playing a significant role in the life of the author and his protagonists as well as in the contents and form of his works.
\end{abstract}

Keywords: civilization, contemporaneity, life, oeuvre, railway

Zygmunt Zbyrowski, Uniwersytet Kazimierza Wielkiego w Bydgoszczy, Bydgoszcz Polska, zygmunt.zbyrowski@gmail.com

ORCID ID: 0000-0001-8601-7580

Za życia Borisa Pasternaka (1890-1960) w Rosji zachodziły głębokie przemiany cywilizacyjne, technologiczne. Dotyczyło to sposobów poruszania się w przestrzeni oraz kontaktowania się na odległość. Coraz doskonalsze środki komunikacji powstawały dzięki elektryczności i wykorzystaniu benzyny. Pasternak znał te wszystkie przejawy nowoczesności i korzystał, przynajmniej z niektórych, na co dzień.

Należało oczekiwać, że znajdzie to wyraz i potwierdzenie $w$ utworach autobiograficznych, korespondencji i twórczości. Sądząc jednak z tych świadectw, nowości technologiczne nie odgrywały istotnej roli w życiu pisarza i bohaterów, rzadko nawet są po prostu wymieniane. Można odnieść wrażenie, że korzystając z nich, prawie ich nie zauważał. Do pewnego stopnia wynikało to z faktu, że większość tych utworów, poza wierszami, dotyczyła przeszłości, przeważnie kończyły się w latach dwudziestych, kiedy zmiany zapoczątkowane $\mathrm{w}$ dobie nowoczesności jeszcze ciągle nie były szeroko upowszechnione.

Warto się temu bliżej przyjrzeć. Pasternak pozostawił dwa utwory autobiograficzne: List żelazny (Охранная грамота) і Szkic do autobiografii (Люди и положения). Przez całe życie w Moskwie jeździł środkami komunikacji miejskiej (autobusy, tramwaje, trolejbusy, taksówki, metro). Innej możliwości nie było. Dojeżdżał do gimnazjum, spotykał się z rodziną, przyjaciółmi, znajomymi, utrzymywał kontakty z różnymi instytucjami. Nigdzie nie opisuje żadnych wydarzeń, w których te środki komunikacji odegrałyby jakąś rolę. Po prostu stwierdza, że przebywał w pewnych miejscach, spotykał się z różnymi ludź- 
mi. Tylko trzykrotnie wspomina tramwaj. Innych środków lokomocji nawet nie wymienia. Od 1935 roku w Moskwie działało metro, a więc przez ćwierć wieku towarzyszyło mu i niewątpliwie musiał z niego korzystać. Ale samą nazwę spotykamy tylko raz. Dwukrotnie mówi o metrze w Berlinie podczas kilkumiesięcznych pobytów w tym mieście w latach 1905-1906 i 1922-1923. W Paryżu (1935) już metra nie zauważył.

Częściej spotykamy nazwy pojazdów w bogatej korespondencji i wspomnieniach różnych osób. Samochody, taksówki, autobusy pojawiają się 8 razy, tramwaje 10 razy. Interesujący jest stosunek pisarza do komunikacji lotniczej. Z korespondencji i wspomnień dowiadujemy się, że latał samolotami, ale autorzy piszą o tym nie ujawniając szczegółów, wrażeń, jakby to było dla nich czymś zwykłym, niezasługującym na uwagę.

Przypuszczalnie po raz pierwszy leciał samolotem w czasie wojny, z Czystopola na Uralu, gdzie ewakuowano jego rodzinę, do Moskwy. Wspomina o tym żona, Zinaida Pasternak: „B декабре 1941 г. Боря улетел в Москву по делам" [1989: 207]. W liście do kuzynki Olgi Freidenberg z 2 listopada 1945 roku Boris informuje ją zwięźle o swoim locie do Tbilisi i z powrotem, jak o czymś zwykłym, niezasługującym na uwagę [Пастернак 1990a: 217]. Było to związane $\mathrm{z}$ udziałem $\mathrm{w}$ uroczystościach jubileuszowych wielkiego romantycznego poety gruzińskiego, Nikołoza Barataszwilego, którego poezję tłumaczył Pasternak.

Ze wspomnień żony Zinaidy Pasternak i przyjaciółki Niny Tabidze, wdowy po wybitnym poecie gruzińskim Tycjanie Tabidze, dowiadujemy się, że do Gruzji leciał również drugi raz. Obydwie wspominają przylot małżeństwa Pasternaków do Tbilisi w 1959 roku. Władze zasugerowały poecie, by opuścił Moskwę na czas pobytu premiera Wielkiej Brytanii MacMillana. Obawiano się, że mnóstwo zachodnich dziennikarzy zechce się spotkać z poetą. Zinaida Pasternak wspomina: „Я послала телеграмму Н. А. Табидзе, сообщая, что вылетаем с Борей в Грузию [Пастернак 1993: 226]. Pasternak chciał również wracać samolotem, ale żona nie zgodziła się: „Он снова настаивал на самолете, а я боялась обратного пути (...) ему наврали, будто на самолет билетов не было" [Пастернак 1993: 227]. W twórczości Pasternak samolotu nawet nie wymienia.

Podobny jest jego stosunek do sposobów kontaktowania się. W autobiografiach o korzystaniu $z$ telefonu pisze czterokrotnie, o telegrafie dwukrotnie. Natomiast z korespondencji dowiadujemy się, że ciągle korzystał z połączeń telefonicznych i często wysyłał i otrzymywał telegramy.

Bogatym źródłem wiedzy o roli nowoczesnych środków komunikacji w życiu Pasternaka są wspomnienia ludzi bliskich, rodziny, przyjaciól, którzy doskonale znali jego życie codzienne. Dowiadujemy się, że już jego rodzice na początku lat dwudziestych posiadali prywatny telefon, po ich wyjeździe 
(w $1921 \mathrm{roku}$ ) mieszkanie przekształcono w komunalne i telefon był do dyspozycji wszystkich lokatorów, w tym również Pasternaka. W połowie lat 30. w nowym mieszkaniu Pasternakowie również mieli prywatny telefon. Raz odegrał on niezwykłą rolę. Chodzi o szeroko znaną rozmowę z inicjatywy Józefa Stalina, dotyczącą Osipa Mandelsztama. Przypuszcza się, że rozmowa z wodzem mogła go chronić przed gorszymi represjami. Autorzy wspomnień potwierdzają częste korzystanie z połączeń telegraficznych. Okazuje się, że rodzina posiadała radio, telewizor, a nawet magnetofon, choć te urządzenia były używane rzadko.

Niezwykle interesujący i charakterystyczny jest stosunek pisarza do komunikacji samochodowej. Z różnych jego wypowiedzi można wyciągnąć wniosek, że nie korzystał z prywatnych samochodów osobowych, nawet taksówek. Przy wyjazdach na wczasy z dworców na dacze dojeżdżano pojazdami konnymi. Można zauważyć obfitość i różnorodność słów z tym związanych (konie, jazda wierzchem, siodło, kibitka, trojka, jamszczyk, kareta, kolaska, wóz, sanie, lichacz, podwoda, tarantas). Ze wspomnień dowiadujemy się jednak, że pod koniec życia pisarza Pasternakowie posiadali własny samochód. W zaskakującym kontekście, dotyczącym represji pisarzy żydowskich, wspomina o tym Korniej Czukowski w swoim dzienniku z 8 sierpnia 1959 roku. Przytacza on wypowiedź Walentego Katajewa o Pasternaku na konferencji prasowej: „Вы воображаете, что он жертва. Будьте покойны он имеет чудесную квартиру и дачу, имеет машину, богач, живет себе припеваючи, получает большой доход со своих книг" [1994: 288]. Można przypuszczać, że rodzinnym kierowcą był wówczas młodszy syn Pasternaka, dwudziestoletni Leonid. Z całą pewnością prywatnych samochodów używali obydwaj synowie pisarza.

W tym miejscu trzeba wspomnieć o tragicznym, rodzinnym wydarzeniu, w którym decydującą rolę odegrał właśnie prywatny samochód. W 1976 roku, w wieku 38 lat, zginął w wypadku Leonid. Prowadząc własny samochód, wskutek zawału serca, stracił przytomność i spowodował wypadek, który zakończył jego życie.

Ze wspomnień możemy się dowiedzieć, że z samochodów, w szczególności z taksówek, korzystali goście i dziennikarze odwiedzający poetę w Pieriediełkinie. Czasem samochodu używały służby śledzące dom pisarza. Pisze o tym Lidia Czukowska, wnuczka Kornieja Czukowskiego, 28 października 1958 roku. Po odwiedzinach u chorego dziadka postanowiła wstąpić do Pasternaka:

По ту сторону нашей улицы, между нами и воротами Сельвинских, у обочины стояла машина. „Победа”, что ли? Она и утром, когда я пришла со станции, была тут же (...) Сейчас я рассмотрела четверых одинаково одетых мужчин, погруженных в чтение одинаково раскрытых газет. На меня они даже и не взглянули, но идя своей дорогой к шоссе, я все время чувствовала затылком провожающие меня восемь глаз [1993: 429]. 
Później dodała uwagę: „Как я узнала впоследствии от Вячеслава Всеволодовича Иванова, прямо напротив дачи Пастернака в этот день и еще 2-3 дня спустя дежурил «Виллис», оснащенный подслушивающими приборами" [Чуковская 1993: 429].Widzimy, jak różne role, pozytywne i negatywne, odgrywały samochody osobowe w życiu Pasternaka i jego rodziny. Natomiast nie znalazło to żadnego potwierdzenia w jego twórczości.

Dokonany przegląd pozwala wyciągnąć wniosek, że Pasternak i jego rodzina nie unikali nowoczesnych środków komunikacji. Natomiast pisarz nie doceniał ich roli, nie podkreślał ich znaczenia w różnych wydarzeniach życiowych. Przypuszczenie, że w ogóle je zauważał wynika z tego, że przelotnie wymieniał ich nazwy. Nie ulega wątpliwości, że przyroda i kultura były mu bliższe niż nowoczesna cywilizacja z jej technicznymi nowościami i osiągnięciami. Pasternak przytacza dowcipny komentarz Majakowskiego: „С обычным юмором так определил наши несходства: «Ну что же. Мы действительно разные. Вы любите молнию в небе, а я в электрическом утюге»" [Пастернак 1983: 42-43].

Te spostrzeżenia znajdują pełne potwierdzenie w twórczości Pasternaka. Nowoczesne środki komunikacji nie odgrywają znaczącej roli w fabułach utworów, w życiu bohaterów, w ich działaniach, przeżyciach, myślach, podejmowanych decyzjach. W zasadzie nie korzystają oni z elektryczności. Rzadko nawet nazwy udogodnień są wymienione w narracji, dialogach bohaterów. Częściej spotykamy pojazdy konne, światło świec. W tym miejscu można zwrócić uwagę na motyw w Doktorze Żywago: „Свеча горела на столе, свеча горела" [Пастернак 1989: 91]. Można odnieść wrażenie, że nieprzypadkowo pisarz pomija te elementy cywilizacji.

Istnieje jednak jeden, niezwykle charakterystyczny, rzucający się w oczy wyjątek. To kolej żelazna. Jest to jedyny nowoczesny środek komunikacji, który zwrócił uwagę badaczy twórczości Pasternaka [Bobryk, Faryno 1999: 243-246; Klimowicz 1992: 55-69; Pogonowska 2016: 62-80; Канатова 2013: 225-232; Непомнящих 2012: 92-105; Флакер 2001: 219-225; Фомичев 2001: 56-62; Фомичев 2007: 333-352]. Autorzy zwracają uwagę na fakt kontynuowania przez niego wątku kolei, pojawiającego się w poezji Afanasija Feta, Nikołaja Niekrasowa, Andrieja Biełego. Doszukują się oni symbolicznych znaczeń, w szczególności przeciwstawienia motywu życia i śmierci, gdzie życie uosabia przyroda, zaś śmierć - kolej żelazna.

Pociągi odgrywają niejednokrotnie decydującą rolę w życiu Pasternaka. Od najmłodszych lat jeździł pociągami, z rodzicami do dziadków w Odessie, latem na dacze. Można wymienić kilka ważnych kierunków jego podróży. Poza Odessą jeździł do Petersburga, na Ural, do Gruzji i za granicę - do Niemiec (Berlin - 1905-1906, 1922-23, Marburg - 1912), do Włoch (Florencja, We- 
necja - 1912) i Francji (Paryż - 1935). Pociągiem podmiejskim dojeżdżał stale do Pieriediełkina.

Na szczególną uwagę zasługują trzy podróże, które wywarły wpływ na życiowe i twórcze decyzje Pasternaka. Poświęca im szczególną uwagę $\mathrm{w}$ utworach autobiograficznych. Zajęły również pewne miejsce $\mathrm{w}$ twórczości.

List żelazny zadedykowany pamięci wybitnego austriackiego poety-modernisty Rainera Marii Rilkego, rozpoczyna pisarz opisem epizodu na dworcu i w pociągu. W 1900 roku rodzina wybierała się do dziadków do Odessy. Dziesięcioletni Boris był świadkiem spotkania rodziców z Rilkem i jego przyjaciółką oraz kochanką Andreą Lu Salome, którzy jechali do Jasnej Polany, w odwiedziny do Lwa Tołstoja. To był jedyny raz, kiedy Pasternak spotkał osobiście poetę austriackiego, którego twórczość uwielbiał. W połowie lat dwudziestych planował spotkanie i wspólne inicjatywy wydawnicze również z udziałem Mariny Cwietajewej. Przedwczesna śmierć Rilkego w wieku 50 lat (w grudniu 1925 roku) uniemożliwiła urzeczywistnienie tych zamiarów. Pasternak był pierwszym tłumaczem Rilkego w Rosji, a jego wiersze zainaugurowały twórczość przekładową poety rosyjskiego [Zbyrowski 2016: 27-38].

Drugie ważne i dramatyczne wydarzenie związane z pociągiem miało miejsce podczas semestralnych studiów na niemieckim uniwersytecie w Marburgu w 1912 roku [Klimowicz 2005]. Tam odwiedziły go w drodze do Berlina siostry Ida i Helena Wysockie, córki zamożnego hurtownika herbaty. Ich rodziny przyjaźniły się. Idzie, swej rówieśnicy (1890-1979) Boris pomagał w przygotowaniu do matury. Ona traktowała ich stosunki jako koleżeńskie. Otoczenie - $\mathrm{w}$ tym obie rodziny - wiedziało o uczuciowym zaangażowaniu Borisa, ale nie traktowano tego poważnie.

W czasie trzydniowych odwiedzin oprowadzał siostry po mieście i okolicy. W hotelu, przed pożegnaniem, pod wpływem nagłego impulsu, wyznał jej miłość i oświadczył się. Było to zdarzenie zupełnie nieprzygotowane, nie dokonał wcześniej rozeznania szans powodzenia. Spotkał się ze zdecydowaną odmową. Oto jak sam Pasternak wspomina najbardziej dramatyczne chwile na dworcu:

Лишь только я понял, что простился с одною младшей, со старшей же еще и не начинал, у перрона вырос плавно движущийся курьерский из Франкфурта. Почти в том же движении, быстро приняв пассажиров, он быстро взял с места. Я побежал вдоль поезда, и у конца перрона, разбежавшись, вскочил на вагонную ступень [Пастернак 1983: 224].

Nie miał biletu i pieniędzy na nocleg. Musiał pożyczyć od sióstr. Swoje przeżycia związane z tym wydarzeniem wyraził w napisanym kilka lat później (1916) wierszu Marburg: 
Я вздрагивал. Я загорался и гас

Я трясся. Я сделал сейчас предложение, -

Но поздно, я сдрейфил, и вот мне - отказ.

Как жаль ее слез! Я святого блаженней (...)

[Пастернак 1990b: 114]

Miało to pewien pozytywny skutek. Wstrząs, jaki wówczas przeżył, sam uważa za decydujący dla podjęcia decyzji o poświęceniu filozofii dla poezji. Napisał wtedy wiele wierszy, które jednak później nazwał „marburskimi śmieciami".

Trzeci epizod, ważny dla dalszego życia pisarza i również związany z podróżą pociągiem, miał miejsce w 1930 roku. W miejscowości wypoczynkowej Irpeń, 23 kilometry od Kijowa, zebrało się sympatyczne i interesujące towarzystwo. Obok małżeństwa Pasternaków i brata Aleksandra z żoną byli: znany filozof sztuki Walenty Asmus z żoną, krytyk literacki z Kijowa Izaak Berlin z rodziną, pianista Włodzimierz Horowitz z siostrą Glinią oraz wybitny pianista, dyrygent i wykładowca Heinrich Neuhaus z żoną Zinaidą.

Małżeństwa Pasternaków i Neuhausów rozpadały się. Neuhaus miał już nową rodzinę, Pasternakowie praktycznie też żyli w separacji. Między Borisem i Zinaidą Neuhaus zaiskrzyło, zaczęło dojrzewać uczucie miłosne. W podróży powrotnej pociągiem trzy godziny spędzili na rozmowie w korytarzu. Ona opisała to w swoich wspomnieniach [Чуковская 1983: 178-179]. To pozwoliło im znaleźć wspólny język, upewnić się we wzajemnym uczuciu i zapewne przyczyniło się do podjęcia decyzji o trwałym związku i małżeństwie w 1933 roku.

Trudno się więc dziwić, że pociągi odgrywały również wyjątkową, czasem wręcz decydującą, przełomową rolę w fabułach utworów, w życiu, losach i podejmowanych decyzjach, uczuciach bohaterów wielu utworów, tak poetyckich, jak i prozatorskich. Można odnotować dużą ilość i różnorodność słownictwa związanego z koleją żelazną. Poza samym słowem „kolej” powtarza się mnóstwo innych pojęć związanych z tym środkiem transportu. Oto one: pociąg elektryczny, wąskotorowy, peron, tory, dworzec, stacja, przystanek, poczekalnia, bufet, rozkład jazdy, kasa biletowa, bilet, parowóz, wagon, przedział, korytarz, semafor, eszelon, depo, tambur, pasażer, maszynista, palacz, konduktor.

Pociągi, w odróżnieniu od innych środków komunikacji, odgrywają również dużą rolę w życiu bohaterów. Podróże pociągami zajmują ważkie miejsce $\mathrm{w}$ fabule i narracji Doktora Żywago. Towarzyszą bohaterom również $\mathrm{w}$ innych utworach poetyckich i prozatorskich, są miejscem ważnych spotkań, uczestniczą w przeżyciach postaci literackich. Epizody rozgrywające się na dworcach lub w pociągach spotykamy już we wczesnych opowiadaniach: Kreska Apellesa (Anелnесова черта), Listy z Tuty (Письма из Tулы), w Dzieciństwie Luwers (Детство Люверc) i w Opowieści (Повесть) [Rożek 1993: 9-18]. 
W utworach poetyckich spotykamy również pojęcia związane z koleją żelazną. Za przykład można uznać poemat 905 rok (905 год), powieść wierszem Spektorski (Спекторскиü) oraz tytuł wiersza Dworzec (Вокзал) czy cykl We wczesnych pociagach (На ранних поездаx). Pociągi nie mają w nich większego znaczenia, choć wiersz Dworzec zaczyna się od swoistego wyznania:

Вокзал, несгораемый ящик

Разлук моих, встреч и разлук,

Испытанный друг и указчик,

Начать - и не исчислить заслуг

[Пастернак 1990b: 79]

Cykl We wczesnych pociagach (На ранних nоездаx) poświęcony jest pobytowi w Gruzji w połowie lat trzydziestych oraz dojazdom przez blisko ćwierć wieku z Pieriediełkina do Moskwy, związanym z tym obserwacjom, wrażeniom i refleksjom. W poemacie 905 rok i powieści wierszem Spektorski pociągi również się pojawiają, ale nie mają większego znaczenia w kontekście wymowy całości.

Natomiast w poemacie Lejtnant Szmidt (Лейmнанm Шмидm) obok głównego, ważnego tematu rewolucji pojawił się wątek uczuciowy. Tytułowy bohater na wyścigach w Kijowie zapatrzył się w młodą kobietę, ona widocznie zauważyła to i też była zainteresowana, lecz nie nawiązali kontaktu, on zgubił ją w tłumie:

Когда я увидал вас [...]

И разом начал взглядом вас преследовать,

И потерял в толпе за турникетом

[Пастернак 1990b: 271]

Następnie nieoczekiwanie znaleźli się w jednym przedziale pociągu:

Когда прошел столбняк моей бестактности

Я спохватился, что не знаю, кто вы.

Дальнейшее известно. Трудно стакнуться,

Чтоб встретиться столь баснословно снова.

Вы вдумались ли только в то, какое здесь

Раздолье вере! - оскорбиться взглядом,

Пропасть в толпе, случиться ночью в поезде,

Одернуть зонт и очутиться рядом!

[Пастернак 1990b: 271]

Zaczęła się ich korespondencja, wyznali sobie miłość, on wybierał się do niej do Petersburga. W ostatniej chwili marynarze wciągnęli go do buntu, za co został skazany na śmierć. Ona dowiaduje się o tym z gazet, jedzie po- 
ciągiem do Romien. W przedziale czyta jego listy, pod wpływem impulsu wysiada, pokonuje liczne przeszkody, by uzyskać widzenie. Bez spotkania $\mathrm{w}$ pociągu uczucie nie miało szansy się rozwinąć.

W wielu utworach prozaicznych pociąg odgrywa istotną funkcję kompozycyjną, narracyjną, ideową i psychologiczną. Doskonałą ilustracją jest wczesne opowiadanie Kreska Apellesa (Anелnесова черта). Autor opisuje szczegółowo pożar dworca (przypuszczalnie w Ferrarze) i wywołany tym chaos. W opisie zwraca uwagę duża ilość słów związanych z koleją. Akapit składający się z 20 wierszy zawiera aż 16 pojęć kolejowych. $Z$ fabuły dowiadujemy się, że wybitny niemiecki poeta-romantyk Heinrich Heine jedzie pociągiem -pewnie do Ferrary - i później ogłasza w miejscowej gazecie, że w przedziale pociągu, pod siedzeniem, znalazł notatnik z rękopisami popularnego poety Relinkwimini oraz, że można go odebrać w hotelu, w pokoju numer 8 . Właściciel notatnika wyjechał z Ferrary na miesiąc, a więc poeci nie mogą się spotkać, ale zgłasza się jego ukochana Kamila Ardence. W wyniku spotkania i rozmowy z poetą kobieta nieoczekiwanie zjawia się w jego pokoju, przypuszczalnie na miłosną schadzkę. Tu pociąg stwarza pretekst do nawiązania romansu, co jest treścią utworu.

W Listach z Tuły (Письма из Тулы) pociąg i dworzec stanowią klamrę kompozycyjną. Narracja zaczyna się od przyjazdu pociągu z Moskwy, kończy się odjazdem do Moskwy. Dworzec jest miejscem akcji, odgrywa rolę tła dla niepowiązanych ze sobą wydarzeń, przeżyć i refleksji. Kolej nie pełni tutaj funkcji ideowej lub psychologicznej, ale terminologia kolejowa jest bogata i urozmaicona.

Pociąg odegrał ważną rolę w przeżyciach Żeni, tytułowej bohaterki opowieści Dzieciństwo Luwers (Детство Люßерс) [Iunggren 1991: 137-158]. Było to związane z podróżą z Permu, gdzie dotąd mieszkała jej rodzina, do Jekaterynburga, gdzie odtąd mieli zamieszkać. Dla niej była to podróż pełna wrażeń. Pociąg przekraczał granicę między Europą i Azją, mijał Ural. Dziewczynka z ogromnym przejęciem przyjmowała to do wiadomości, obserwowała i podziwiała zmieniające się widoki, zjawiska przyrody. To wzbogacało jej psychikę, sprzyjało uczuciowemu dojrzewaniu, budziło zdolność do refleksji.

W Opowieści odnajdziemy wątek podróży pociągiem głównego bohatera Sierioży, ale nie ma on większego znaczenia w kontekście jego losu i przeżyć. Trochę rozmyśla, większą część podróży śpi. Towarzyszy swoim pracodawcom jako wychowawca ich syna, ale rozstaje się z nimi i dociera do swej siostry.

Pociągi i odbywane nimi podróże, dworce i ich otoczenie, odgrywają wyjątkową i różnorodną rolę w powieści Doktor Żywago (Доктор Жиъаго). Wielu bohaterów mieszka w okolicy dworca Brzeskiej Kolei Żelaznej, a niektórzy 
związani są ze środowiskiem kolejarzy. Szczególną rolę odgrywają w wydarzeniach rewolucyjnych. Dotyczy to przede wszystkim rodziny Antipowów. Ojciec rodziny jest jednym z przywódców rewolucji 1905 roku na kolei, a w czasie wojny domowej członkiem trybunału rewolucyjnego, zaś jego syn Paweł, mąż Lary, komisarzem bolszewickim.

Na samym początku powieści mały Jurij Żywago obserwuje nieoczekiwane zatrzymanie pociągu. Nie wie, że przyczyną jest samobójstwo jego ojca, czego świadkiem jest jego przyszły przyjaciel Misza Gordon. W późniejszej rozmowie z Larą Jurij wspomina o tym wydarzeniu. Do samobójstwa doprowadził prawnik Komarowski, który również jechał tym pociągiem z Syberii do Moskwy. Później ich losy i kontakty wielokrotnie i w różnorodny sposób się przeplatają i łączą ze sobą.

Na początku rewolucji doktor Żywago wracał z frontu pociągiem do Moskwy. W szpitalu w Mieluziejewie najpierw był pacjentem, później tam pracował i poznał Larę, która była w nim pielęgniarką. Przed odjazdem, na dworcu był świadkiem zabójstwa młodziutkiego Ginca. Później, w oddziale partyzanckim spotkał jego zabójcę, który w rozmowie wspomniał o tym. Całą drogę towarzyszył mu głuchoniemy młodzieniec, jedyny współpasażer w przedziale.

Autor bardzo szczegółowo przedstawił podróż rodziny Gromiekowów do Warykina, ich rodzinnej posiadłości, gdzie postanowili schronić się przed niebezpieczeństwami grożącymi im w Moskwie. Podróż opisana jest dokładnie. Jadą w wagonie towarowym. Poznajemy warunki i okoliczności (ślady wojny, usuwanie śniegu z torów) oraz towarzyszy podróży, ich rozmowy i rozmyślania. Najważniejsze było spotkanie i rozmowa w pociągu doktora Żywago z Pawłem Antipowem, mężem Lary, groźnym komisarzem bolszewickim, działającym pod nazwiskiem Strielnikow.

Takich przypadkowych spotkań różnych ludzi w pociągach, najczęściej bez dalszych konsekwencji, było mnóstwo, czasem miały one dalszy ciąg. Podczas wspomnianej podróży Żywago spotkał przelotnie chłopca Wasię Brykina, z którym po ucieczce z oddziału partyzanckiego jechał pociągiem do Moskwy i później się nim opiekował.

Przemieszczanie się pociągami masy ludzi oraz ważnych bohaterów powieści stwarza okazję do przedstawienia burzliwych wydarzeń oraz przemian w latach rewolucji i wojny domowej w Rosji. Kolej żelazna była w tym czasie najlepszym środkiem podróżowania na duże odległości. Pasternak to doskonale wykorzystał. 


\section{Bibliografia}

Канатова М. 2013. К интерпретации стихотворения Б. Пастернака „Пространство”, „Русская филология", nr 24, s. 225-232.

Непомнящих Н. А. 2012. Железная дорога как комплекс мотивов в русской лирике и эпике (обзор), [w:] Е.К. Ромодановская (red.), Сюжетно-мотивные комплексы русской литературы, Новосибирск: Академическое изд. „Гео”, s. 92-105.

Пастернак Б. Л. 1983. Воздушные пути. Проза разных лет, Москва: Советский писатель. Пастернак Б. Л. 1989. Доктор Живаго. Роман. Повести. Фрагменты прозы, Москва: Советский писатель.

Пастернак Б. Л. 1990а. Переписка, Москва: Художественная литература.

Пастернак Б. Л. 1990b. Стихотворения и поэмы, t. 1, Ленинград: Советский писатель.

Пастернак 3. 1993. Воспоминания о Борисе Пастернаке, Москва: Слово/Slovo.

Флакер А. 2001. Освоение пространства поездом (Заметки о железнодорожной прозе Бориса Пастернака), „Slavica Tergestina”, nr 8, s. 219-225.

Фомичев А. С. 2001. Вперед то под гору, то в гору бежит прямая магистраль... (Железная дорога В романе Б. Пастернака „Доктор Живаго”), „Русская литература”, nr 2.

Фомичев А. С. 2007. Пушкинская перспектива, Москва: Знак.

Чуковская Л. 1993. Из дневника. Воспоминания, Москва: Слово/Slovo.

Чуковский К. 1994. Дневник (1930-1969), Москва: Современный писатель.

Bobryk R., Faryno J. 1999. Parowóz wzorowego maszynisty, „Studia Litteraria Polono-Slavica", nr 3, s. 243-246.

Iunggren А. 1991. Урал в повести „Детство Люверс", „Wiener Slawistischer Almanach”, nr 27, s. 137-158.

Klimowicz T. 1992. Aneks do kolejowego rozkładu jazdy. Motyw pociagu i dworca w literaturze rosyjskiej, „Acta Universitatis Wratislaviensis. Slavica Wratislaviensia”, nr LXX, s. 55-69.

Klimowicz T. 2005. Pożar serca. 16 smutnych esejów o miłości, o pisarzach rosyjskich $i$ ich muzach, Wrocław: Wydawnictwo Uniwersytetu Wrocławskiego, źródło elektroniczne: http://niniwa22.cba.pl/tadeusz_klimowicz_pozar_serca_3.htm (dostęp 11.06.2019).

Pogonowska E. 2016. Rosja (nie)objęta koleją. O jednym z aspektów polskich narracji o Rosji, [w:] D. Mazur, B. Morzyńska-Wrzosek (red.), Przestrzeń w kulturze wspótczesnej. Literatura. Teatr. Film, Bydgoszcz: Wydawnictwo Uniwersytetu Kazimierza Wielkiego, s. 62-80.

Rożek L. 1993. Motyw podróży we wczesnej prozie Borisa Pasternaka, „Studia Rossica Posnaniensia", z. XXIV, s. 9-18.

Zbyrowski Z. 2015. Gruzja - „druga ojczyzna” Borisa Pasternaka, „Scripta Humana”, t. 4, s. 78-89.

Zbyrowski Z. 2016. Boris Pasternak i Rainer Maria Rilke, [w:] J. Kazimierczyk-Kuncer (red.), Wschód-Zachód w nieprzerwalnym dialogu, Słupsk: Wydawnictwo Naukowe Akademii Pomorskiej, s. 27-38. 